\title{
The Five Senses of Canadian Cinema: Introduction
}

\begin{abstract}
Since the 1990s the field of film studies has seen a rise in approaches to cinema that accentuate the idea of the body as a complex site of perception. This special issue of Brno Studies in English originated with the call for submissions that would reflect on these developments and apply them to Canadian cinema. The resulting volume has brought together articles by authors of different generations, who use a variety of critical vantage points to address cinematic works from vastly different genres. These range from experimental avant-garde cinema, to (self)reflective documentaries, through more traditional commercial feature films.

This introduction attempts to briefly situate the volume within the relevant theoretical context and present the individual authors and their papers. While highlighting some of the main points the contributors make, it also identifies various thematic and methodological overlaps running through the volume, which are of particular relevance to Canadian cinema and culture.
\end{abstract}

Key words

Canadian cinema; corporeal reception of cinema; Vivian Sobchack; Michael Snow; Zacharias Kunuk; Peter Mettler; Xavier Dolan; Sarah Polley; Atom Egoyan; Patricia Rozema

Since the 1990s the field of film studies has seen a rise of approaches to cinema that accentuate the idea of the body as a complex site of perception. When looking at cinema's nature and impact, there has been a tendency to radically enlarge the critical focus and incorporate other, previously neglected senses: attention has been paid to the aural, tactile, kinesthetic - or haptic - sides of cinema, as well as various other perceptive modalities of the viewer's body. Scholars such as Steven Shaviro, Vivian Sobchack, Laura Marks have described the cinematic experience 
as a multisensory, corporeal one, and called for a distinctly new understanding of the cinema-viewing experience, one much less based on the sense of sight and the notion of the screen as mirror. Echoing the work of Gilles Deleuze, these theoreticians, moreover, have questioned the split of the viewing subject from the objects on the screen, highlighting rather the mutual interconnectedness of cinematic movement, technology, the viewer's body and consciousness in the cinema viewing experience.

In his book aptly entitled The Cinematic Body Steven Shaviro describes the cinematic experience in the following manner:

Cinema invites me, or forces me, to stay within the orbit of the senses. I am confronted and assaulted by a flux of sensations that I can neither attach to physical presences nor translate into systematized abstractions. I am violently, viscerally affected by this image and this sound, without being able to have recourse to any frame of reference, any form of transcendental reflection, or any Symbolic order. (Shaviro 1993: 32)

In addition to a total corporeal response on the part of the viewer, Shaviro highlights the full immersion of the spectator within the spectacle. Following Deleuze, he stresses the continuity between the perceiving subject and the sensory stimuli of cinema and he puts a great deal of weight on cinema's prescient affective nature.

Similarly to Shaviro, Vivian Sobchack is convinced that making sense of cinema depends to a great extent on more senses than vision alone. In a telling passage Sobchack recalls her first viewing experience of Jane Campion's The Piano (1993) and describes her original reaction to the film's opening moments. The narrative of the film starts with a blurred point of view shot of the heroine Ada, staring through her fingers covering her eyes:

What I was seeing was, in fact, from the beginning, not an unrecognizable image, however blurred and indeterminate in my vision, however much my eyes could not "make it out." From the first (although I didn't consciously know it until the second shot), my fingers comprehended that image, grasped it with a nearly imperceptible tingle of attention and anticipation and, offscreen, "felt themselves" as a potentiality in the subjective and fleshy situation figured onscreen. And this before I refigured my carnal comprehension into the conscious thought, "Ah, those are fingers I am looking at." (Sobchack 2004: 63)

Working through the phenomenology of Merleau-Ponty, Sobchack repeatedly stresses the notion that the viewers make sense of cinema through other senses than vision alone. At the same time she describes "embodiment [as] a radically material condition of human being that necessarily entails both the body and consciousness, objectivity and subjectivity, in an irreducible ensemble" (Sobchack 2004: 4). 
Highlighting the unique characteristics of intercultural cinema, Laura U. Marks coins the term "haptic visuality":

Haptic cinema does not invite identification with a figure - a sensory motor reaction - so much as it encourages a bodily relationship between the viewer and the image. Consequently as in mimetic relationship, it is not proper to speak of the object of a haptic look as to speak of a dynamic subjectivity between looker and image. [...] In revaluing haptic visuality I am suggesting that a sensuous response may be elicited without abstraction. (Marks 2000: 64)

Again, we encounter here a very similar set of ideas, only conveyed by means of a slightly different terminological repertoire.

When issuing the call for papers for a special issue of Brno Studies in English, I asked potential contributors to consider submissions that would combine such approaches with a thematic focus on Canadian cinema. Contributors were invited to reflect on the variety of ways in which Canadian filmmakers, past and present, have engaged the senses and the body in their works and how these representations have impacted their concrete and corporeal viewers. The resulting volume has brought together articles by authors of different generations, who use a variety of theoretical vantage points to address cinematic works from vastly different genres; these range from experimental avant-garde cinema, to (self)reflective documentaries, through more traditional commercial feature films. And yet several common threads can be discerned across the individual submissions to the volume: in addition to the question of embodiment and/in the cinematic experience, some authors, looking at avant-garde and documentary films, have addressed questions of landscape representation as well as the question of technology and its crucial role in the process of mediation. These essays form the first part of the volume. In the second group of essays, where narrative cinema is under scrutiny, their authors focused particularly on the existence of permeable, problematic boundaries between various entities, and pointed at the multiple "in-between spaces" the film makers create, visualize and explore.

\section{Part One: Bodies, Landscapes, Representation}

This special issue of Brno Studies in English starts with an article surveying the film projects of the avant-garde artist Michael Snow. The films of this versatile artist have been traditionally described as conceptual or structuralist. And yet, Dan Browne highlights the degree and manner in which this Canadian creator, throughout his whole cinematic work, intentionally elicits a corporeal response from viewers. For Snow, just as for some other film makers and scholars referred to or represented in this volume, the body is understood "as a primary mediation for all perceptual activity, an inescapable condition of the world". Browne examines and comments on Snow's methods, which primarily lie in a creative use 
of the recording technology with the objective of challenging traditional modes of representation. Browne approaches Snow's work via Aristotle's and Aquinas' (and also Marshall McLuhan's) notion of the sensus communis. According to Aristotle and Aquinas, this sense "forms an integral component of consciousness, serving as the connective bridge through which 'all sensible qualities are related"'. If McLuhan describes modern technology as an extension of the human sensorium, technology can at the same time be regarded as an extension of the sensus communis, too, i.e. "forming and an integral part of human perception and consciousness". Snow's artistic work in general, and his cinema in particular, then offers an interpretation of technology that is closely connected to the famous thesis of the popular Canadian media theorist.

Browne not only informs us about Snow's work as in tune with what Arthur Kroker labels the Canadian discourse on technology, he also perceptively describes how Snow's artworks challenge the mode of traditional linear visual representation of landscape. The problematic of representing landscape as a contested terrain where deeply ingrained epistemological assumptions - and representational conventions - collide, lies at the heart of Samantha Wilson's article "Sirmilik, Geographical Experience, and the Question of Landscape". In her essay Wilson employs a predominantly (but not exclusively) Heideggerian perspective to discuss the creative solutions taken by the Inuit film maker Zacharias Kunuk to represent the National Park Sirmilik in Canada's Nunavut Province. Kunuk's documentary was commissioned as an installment of a joint project involving a documentary consisting of a series of short films about the Canadian National Parks, entitled The National Parks Project (2011). Such programs have a general tendency to adhere to a traditional landscape aesthetic, which typically offer viewers aerial shots and majestic vistas, as presented by the separate, disembodied and transparent lens of the camera. The impact of such shots is one of a distanced gaze, marked by contemplation and abstraction, following the tradition of the Renaissance perspective. Such an aesthetic, predominant in the Western world since the time of the Renaissance, has traditionally been employed to evoke the feeling of aesthetic contemplation and/or human (colonial) mastery over the landscape.

Wilson demonstrates that while Kunuk in his film does not refrain from using such traditional approaches, he also attempts to represent the national park from the perspective of its Inuit inhabitants. In so doing he avails himself of a "hybrid aesthetic where the gaze of the viewer is reattached to the motion of the body mark[ing] a shift in the privileging of the gaze over the body in the breakdown of distance". Images of Inuits traveling in snowmobiles in the park, whose perspective we share along with the camera - in a fragmented and intentionally incomplete manner - thus provide an alternative aesthetic, one which expresses Heidegger's notion of readiness-to-hand, which refers "to our direct immediate relationship with the objects of the world".

In her article Wilson reminds us that "everyday experiences with the environment, natural and built, are often overlooked in geography" while at the same 
time having "a fundamental effect on every other form of knowledge production" and that "the term landscape exists at a nexus of immersion and detachment".

Her claim resonates remarkably well with ideas expressed in the article by Darrell Varga. Describing the documentaries by Jennifer Baichwal, Varga points out that Baichwal's films offer their viewers "immersive and embodied experiences in a dialectic of thought and geography". Her films are not "cast in the model of the Griersonian documentary," with its clear, rational organization and much too facile claims as to the veracity of the representation of the recorded events. On the contrary, Varga describes Baichwal's works as marked by the use of "images of space, time and chance [...] in order to provoke questions of process and representation" - In the film True Meaning of Pictures: Shelby Lee Adams' Appalachia (2004), for instance, Baichwal is at once "signal[ing] a distance from documentary objectivity and remind[ing] us that the process of mediation is always produced at a calculated remove from the real. It is in this discourse of calculations that arises the key tensions of the work".

Varga furthermore attempts to understand cinematic representation in the "broad context of culture and power" and regards the documentary film process as a manifestation of the oral tradition. This particular claim is underpinned by the ideas of the Canadian communication theorist Harold Innis, who saw "culture as forming out of the confluence of spacial and temporal biases, with the spacial associated with writing and the temporal associated with orality". Documentaries, such as those by Jennifer Baichwal, are, according to Varga, firmly rooted within the oral tradition.

Obviously, neither feature films nor documentaries result from the efforts of a sole creative genius, but are collective endeavors. Baichwal's more recent films, such as Manufactured Landscapes (2006) and Watermark (2013), stem from the collaboration of Baichwal with the photographer Ed Burtynsky. Such collaborations can be very productive in the way the individual approaches of the artists clash: "Burtynsky's focus on the grand gesture and Baichwal's search of the personal stories present within the landscape."

Stress on the self-reflexive representation of landscape; an alternative phenomenology of the viewing subject; skepticism about the possibility of an unproblematic way of representing the world in contemporary media society - and the personality of Manufactured Landscapes' cinematographer Peter Mettler - are some of the main links connecting Darrell Varga's essay with the ensuing text by Nathan Clarkson. In his essay "Aura, Aurora and Aurality: The Narrative of Place in Picture of Light" Clarkson examines Mettler's documentary Picture of Light (1994) in an attempt to demonstrate "how narrative, technique and technology can all be traced to the placement of the body in space over time and how these themes are used in the film to create an experience that [...] that creates an aura of the attempt to represent the Aurora Borealis on film".

Approaching Mettler's documentary from a variety of positions, Clarkson's analysis of the film is based on a range of theoretical vantage points that include thinkers such as Marshall McLuhan, Walter Benjamin, Laura Marks, Jean-Luc 
Nancy, and Pierre Bourdieu. While the use of haptic theory allows Clarkson to remark on Mettler's intentional problematization of the separation between the viewing subject and the object, interpreting the film via Jean-Luc Nancy "provides a rich foundation for exploring the audiovisual representation of film as it relates to the perception of space within the film". Both Nancy and Mettler, we are told, "question the relationship between knowledge and experience, as well as notions of interior and exterior" just as the film "explores the possibility of experience through the limitation of representation".

\section{Part Two: Permeable Boundaries, Places In-Between}

Mettler's highlighting of "the permeable boundaries between the subject and audience, image and sound, and immersion and reflexivity," and his deliberate creation of in-between spaces, appear to be some of the most successful features of his unusual film. A strong sense of liminality, a sense of being in-between, along with the unsettling of traditional boundaries and "easy assumptions about the relationships of surface and depth, image and self, fantasy and bodily reality" represent some of the main points of Jim Leach's article on Sarah Polley's Take This Waltz (2011) and Xavier Dolan's Laurence Anyways (2012). Leach argues that although these two features did not generally receive favorable reviews at the time of their release, they are definitely worth a closer look, "because of the ways in which they belie their initial appearances to explore characters undergoing changes that leave them in 'in-between' states that call into question the categories through which their culture (including movies) defines what is 'normal' and tries to regulate gender and identities". Thus we see Margot (Michelle Williams), the heroine of Polley's film, caught between two different partners, the not so exciting husband Lou (Seth Rogen), and the artist Daniel (Luke Kirby); the position of being in-between of the principal character Laurence (Melvil Poupaud) from Dolan's film may not be so explicitly formulated but is more profound: s/he happens to be caught, literally, between genders as $\mathrm{s} / \mathrm{he}$ is planning to undergo a sex-change operation.

Leach goes on to argue that both young directors have created stories, in which it is also hard to delimit the boundaries between various fantasies and embodied realities. Moreover, he claims "the stories [both] films tell resonate within, but are not limited to, the national culture in which they are embedded," not only by virtue of the positions they take on the issues of gender and sexuality, but also because both Polley and Dolan remain "suspicious of the happy ending associated with Hollywood". (Canadian feature films, at least those that have been canonized, as a rule avoid such facile and conventional closures.)

The condition of finding oneself somewhere in-between pervades another Sarah Polley film, her successful debut feature Away from her (2006), an adaptation from Alice Munro's story "The Bear Came over the Mountain," which is the subject of the essay by José Rodriguez Herrera. This award-winning film focuses on the character of Fiona (Julie Christie), who is caught in the precarious condition 
between sanity and the gradual onset of a neurodegenerative disease. Herrera stresses "how Polley's film [just as Munro's story] destabilizes the frontiers between forgetfulness and remembrance, sense and nonsense, sanity and dementia". Fiona's in-betweenness is further highlighted as she is moved to a mental institution where she starts a romance with another patient. Ironically, her husband Grant (Gordon Pinsent), who had been a philanderer in the past, is forced into the role of a "procurer of romance" between his wife and her new friend, for this relationship appears to have a beneficial effect on his wife's condition.

Herrera comments on the standard of the adaptation, comparing Munro's story with Polley's film and illustrates Polley's creative interventions on the thematic front (for instance Fiona's getting lost while going out to ski). He also highlights some of the formal cinematic techniques Polley used, such as "reversal" and "space-off", which resulted in a successful translation of Munro's text and imbued it with a distinct feminist slant.

The problematization of borders forms also the core of the next study of this special issue. In this article, it is the borders of national identity, which are called into question, particularly in regard to the body. André Loiselle looks at a group of selected American horror films made in Canada "which focus on American corporality as the embodiment of the abjection that Canadians deny in themselves and project onto the monstrous US". Loiselle comments on the slasher film American Nightmare (2002), the actual setting of which can easily be recognized as Toronto, and lists the various Canadian elements inserted in this American production. He says: "That a film entitled American Nightmare would be so noticeably Canadian is crucial here, for it manifests the tendency so common in the horror film genre to project onto the other (America) the unbearable abjection that is excruciatingly intolerable in the self (Canada)." His discussion of the film is duly contextualized, reminding the readers of the dark side of the Toronto experience in the 1970s and 1980s, despite the English Canadian metropolis' traditional image of "propriety, respectability and decency".

Loiselle's discussion of American Psycho (2000) includes comparative comments about the film as an adaptation of Bret Easton Ellis's eponymous novel and shifts the body of the protagonist, Patrick Bateman (Christian Bale) into the foreground. "Bateman's body, among other things, represents the incarnation of the endless interchangeability of commodities within rampant consumerism." Remarking on the lack of a sense of identity Bateman perceives, Loiselle pronounces him Canadian, for Bateman's 'Canadian identity' rests precisely in his "self-awareness that he does not have a tangible identity, and that painting layer upon layer of post-modern Americana on his body simply does not help". Even the third film discussed in the article, American Mary (2012), "looks too Canadian to pass as a forceful indictment of American culture". The fact that in the case of all these films we may be looking at a classical instance of repression is furthermore suggested by the insistence, on the part of the film makers, on locating these narratives in America and using the word even in their titles, concludes André Loiselle. 
The selection of the essays in this volume could be used as yet another illustration of Hugh MacLennan's notion of the two solitudes. Nowhere in the first seven essays do we find any analyses of the cinematic production of Canada's other solitude, i.e. Québec. In fact the words Québec and Québecois are conspicuously absent from most submissions. This absence is even more regrettable if we consider the role cinema plays for the articulation of French Canadian identity and experience. A partial correction is provided by Marcel Arbeit's article on the question of communication in Canadian film. While the subject of Québec finally enters the picture here, Arbeit's findings with regard to the mutual communication between the two major constituent parts of Canadian culture give rise to concern in that he identifies severe communication problems between Anglophone and Francophone elements.

Pursuing a number of thematic lines, Arbeit's text tackles various instances of loss and distortion in the process of subtitling. He then focuses on the frustrating misunderstandings monolingual English-speaking characters experience in a Francophone environment and examines the possibilities - and limitations of non-verbal communication by means of different sign systems, as shown in a selection of older Canadian films, in particular Patricia Rozema's Desperanto (1991), Peter Mettler's Tectonic Plates (1992), and Atom Egoyan's En Passant (1991).

What has surfaced as an added value across the special issue in addition to the volume's central thematic focus - i.e. a particular emphasis on the question of embodiment and the role of all five senses in the cinematic experience - appears recognizably Canadian: a strong stress on the questions of mediation in the world saturated by modern communication technology, its role in life in general and the cinematic process in particular; a profound skepticism about unquestioned values and boundaries; and an awareness of uncertainty, and even some misgivings, in regard to Canadian national identity.

\section{Note}

This special issue is dedicated to Thomas Donaldson Sparling, who introduced me to the world of Canadian studies.

\section{References}

Marks, Laura (2000) The Skin of the Film, Intercultural Cinema, Embodiment, and the Senses. Durham and London: Duke University Press.

Shaviro, Steven (1993) The Cinematic Body. Minneapolis, London: University of Minnesota Press. Sobchack, Vivian (2004) Carnal Thoughts, Embodiment and Moving Image Culture. Berkeley, Los Angeles, London: University of California Press. 
Tomáš Pospíšll is Associate Professor at the Department of English and American Studies, Masaryk University Brno. He teaches American literature, American and Canadian film, and American cultural studies. He is the author of The Progressive Era in American Historical Fiction: John Dos Passos' The 42 ${ }^{\text {nd }}$ Parallel and E.L. Doctorow's Ragtime (1998), Prüvodce cestovatele Amerikou (A Traveler's Guide through the Culture of the United States, 2001) and Sambo tu již nebydli? Obraz Afroameričanů v americkém filmu 20. století (Sambo Does Not Live Here Anymore? The African American Representation in American Film of the $20^{\text {th }}$ Century, 2003) He also coauthored the volume Us-Them-Me, the Search for Identity in Canadian Literature and Film (2009), where he contributed a chapter on Canadian feature film. His research interests involve African American film representation and North American film and television.

Address: doc. PhDr. Tomáš Pospíšil, Ph.D., Department of English and American Studies, Faculty of Arts, Masaryk University, Arna Nováka 1, 60200 Brno, Czech Republic [email: Tomas. Pospisil@phil.muni.cz] 
